ISSN 0130-8521. Передгірне та гірське землеробство і тваринництво. 2021. Вип. 70 (2)

DOI: $10.32636 / 01308521.2021-(70)-2-3$

UDC 633.2.03:631.8

T. I. MARTSINKO, candidate of agricultural sciences

A. H. DZIUBAILO, doctor of agricultural sciences

N. V. KARASEVYCH, scientist

Institute of Agriculture of Carpathian Region of NAAS

Hrushevskoho street, 5, v. Obroshyne, Lviv district, Lviv region,

81115,e-mail: tarmarc@ukr.net

\title{
FORMATION OF SOWED MIXTURES OF MEADOW GRASSES UNDER THE INFLUENCE OF MINERAL FERTILIZER
}

The aim of the research was to identify the features of growth, development and formation of elements of productivity of perennial grasses in grass mixtures of hay morphotype depending on the level of mineral fertilizer.

The experiment started in 2016 by the spring uncovered method of sowing on sod-podzolic surface-gleyed medium-acid loamy soils. Were sown perennial grasses: perennial fenugreek - variety Drohobytskyi 16, timothy grass - Pidhirianka, meadow fescue - Liulinetska 3, meadow clover - Peredkarpatska 33 and bird's-foot trefoil - Aiaks.

The grass-stand was fertilized with nitrogen, phosphorus and potassium fertilizers in the form of ammonium nitrate, granular superphosphate and potassium salt. A complex of microelements in chelated form Mikrofol Kombi was used for foliar feeding.

The research results show that the highest dry matter yield of $9.08 \mathrm{t} / \mathrm{ha}$ is formed by sowing meadow clover, bird's-foot trefoil and a mixture of cereal grasses (timothy grass, orchard grass, perennial fenugreek) when applying mineral fertilizers at a dose of $\mathrm{N}_{60} \mathrm{P}_{60} \mathrm{~K}_{60}$. When sowing timothy grass with meadow clover on a similar agricultural background, the yield of dry mass was $8.56 \mathrm{t} / \mathrm{ha}$.

The grass mixture with the original $100 \%$ composition of cereal grasses provided the lowest feed output. On average the yield of dry matter from 1 ha was 2.15-5.92 tons, green mass 9.85-22.58, respectively.

In the clover-timothy grass mixture, the share of meadow clover in the harvest, on average over the years of grass use, remained at the level of 28.5; 28.6; 23.2; 22.7 and $17.0 \%$ in the green mass. In a five-component mix (timothy grass, orchard grass, perennial fenugreek, meadow clover, bird's-foot trefoil) fraction of meadow clover in grass-stand made only 13.8-15.4\%. The content of bird's-foot trefoil on average for four years of use was $11.3-22,8 \%$ of the green mass.

It is established that the mixture of timothy grass with meadow clover provides the highest yield of feed units $-7.07 \mathrm{t} / \mathrm{ha}$ and digestible protein of $1.08 \mathrm{t} / \mathrm{ha}$ with the use of complete mineral fertilizer. The supply of one feed unit with digestible protein reaches $140 \mathrm{~g}$.

(C) Martsinko T. I., Dziubailo A. H., Karasevych N. V., 2021 
Key words: grass mixtures, fertilizers, botanical composition, productivity, dry weight, feed units.

Марцінко Т. І., Дзюбайло А. Г., Карасевич Н. В.

Інститут сільського господарства Карпатського регіону НААН

\section{мінерального удобрення \\ Формування сіяних сумішей лучних трав під впливом}

Метою досліджень було виявити особливості формування елементів продуктивності багаторічних трав у травосумішках сінокісного типу залежно від рівня мінерального удобрення.

Дослід було закладено в 2016 р. весняним безпокривним способом сівби на дерново-підзолистих поверхнево оглеєних середньокислих суглинкових грунтах. 3 багаторічних трав висівали: пажитницю багаторічну сорт Дрогобицький 16, тимофіївку лучну - Підгірянка, кострицю лучну Люлінецька 3, конюшину лучну - Передкарпатська 33 і лядвенець рогатий Аякс.

Травостій удобрювали азотними, фосфорними та калійними добривами у формі аміачної селітри, гранульованого суперфосфату і калійної солі. Використовували комплекс мікроелементів у хелатній формі мікрофол комбі для позакореневого (листкового) підживлення травостою.

Дослідженнями встановлено, що найбільша врожайність сухої речовини $(9,08$ t/ha) формується за сівби конюшини лучної, лядвенцю рогатого і сумішки злакових трав (тимофіївка лучна, грястиця збірна, пажитниця багаторічна) при внесенні мінеральних добрив у дозі $\mathrm{N}_{60} \mathrm{P}_{60} \mathrm{~K}_{60}$. За сівби тимофіївки лучної 3 конюшиною лучною на аналогічному агрофоні урожайність сухої маси становила 8,56 t/ha.

Травосуміш 3 вихідним 100-відсотковим складом злакових трав забезпечила найменший збір корму. За усереднених даних, вихід 31 га сухої речовини становив 2,15-5,92 т, зеленої маси - відповідно 9,85-22,58.

У конюшино-тимофіївковій травосумішці частка конюшини лучної в урожаї в середньому за роки використання травостою зберігалася на рівні 28,$5 ; 28,6 ; 23,2 ; 22,7$ і 17,0 \% в зеленій масі. У п`ятикомпонентній сумішці (тимофіївка лучна, грястиця збірна, пажитниця багаторічна, конюшина лучна, лядвенець рогатий) частка конюшини лучної у формуванні травостою становила лише 13,8-15,4 \%. Вміст лядвенцю рогатого в середньому за чотири роки використання становив 11,3-22,8 \% в зеленій масі.

Встановлено, що сумішка тимофіївки лучної 3 конюшиною лучною забезпечує найвищий вихід кормових одиниць $(7,07 \mathrm{t} / \mathrm{ha})$ i перетравного протеїну $(1,08 \mathrm{t} / \mathrm{ha})$ за використання повного мінерального добрива. Забезпеченість однієї кормової одиниці перетравним протеїном досягає 140 г.

Ключові слова: травосумішки, удобрення, ботанічний склад, продуктивність, суха маса, кормові одиниці. 
Introduction. The basics of the formation of highly productive sown grass-stands provide a sound approach to the development and practical application of effective methods of their creation and rational use.

Sown grasslands, like natural ones, are a holistic system in which all the components are closely linked by metabolic processes. Therefore, a very important issue is the selection of the optimal number of herbs types that are part of the grass mixture. For a long time it was considered expedient to sow complex grass mixtures, which include $8-10$ and even 15 species [1, 5, $7,11,25]$. Later it was experimentally proved that grass mixtures of simplified type of 4-5 species, and on a high agro-background - with a smaller number of species in terms of productivity are not inferior to complex, while significantly reducing seed costs, improving care, more appropriate use of grass with biological characteristics of the main components of herbal mixture.

It should be noted that the grass mixture is a planned mixture of populations, species, varieties of grasses that live and develop according to different patterns than in single-species crops. Each population included in the grass mixture consists of genotypically and phenotypically diverse individuals, has its own optimum, maximum and minimum conditions for the accumulation of organic matter. At the same time, each population in a mixed crop serves as a living condition for others. A change in the number and biomass of one leads to changes in the other components. For each population it is necessary to create such conditions which would provide the greatest yield of all mix during all period of use. Therefore, it is important to know how relationships are formed in the process of their mutual sphere formation, types of behavior of different species in mixtures and changes that occur in the composition of grass mixtures over time $[3,4,7,14,15,21$, 24, 29].

To save energy, it is important to continue the use of legumes in grasslands up to 5-6 years $[3,10,18]$. This can be achieved by including in the grass mixture stable, long-lived types of legumes, the correct mode of use. According to M.F. Davydyuk and others, one of such ways may be to reduce the seeding rate. On average, in three years the highest yield was provided by legume-cereal grass mixture with half the sowing rate of cereals and the generally accepted sowing rate of legume components on the background of phosphorus-potassium fertilizers [7]. Reducing the sowing rates of cereal components at a constant sowing rate of legumes increases the productivity of grasslands by 1.3 times. The highest protein content and collection of feed units is observed in the same variant. This 
technology helps to increase the fixation of biological nitrogen by 2.1 times $[1,10-14,17,19]$.

It is established that after $3-5$ years of grass use with more legume component, soil enrichment by $210-250 \mathrm{~kg} / \mathrm{ha}$ of nitrogen is achieved due to root mass and formation of $7-12 \mathrm{t} / \mathrm{ha}$ of humus [15, 17]. 8 years after sowing of perennial grasses, the stock of humus in the upper $(80 \mathrm{~cm})$ layer increased by 25 t/ha [16]. Perennial legumes increase soil fertility much more than cereals. After all, with their crop-root residues, in the soil remains about $50 \%$ of nitrogen fixed from the air, which significantly increases the yield of subsequent crops for 2-3 years. Perennial legumes are able to form $500-700 \mathrm{~kg} / \mathrm{ha}$ of humus annually, which is equivalent to the application of 20-30 t/ha of manure [10, 23, 26-28]. Also, when growing legumes, a certain part of the phosphorus accumulated by plants remains in the soil and is contained in organic matter (root system), which is easily decomposed by microorganisms.

Clover, depending on the conditions of cultivation and development, during the year can absorb from the air about $140 \mathrm{~kg} / \mathrm{ha}$ of nitrogen, in the soil remains $60-80 \mathrm{~kg} / \mathrm{ha}$. The cost of 1 quintal of feed from clover compared to other forage crops is quite low and it has only $170 \mathrm{~g}$ of digestible protein per 1 feed unit $[10,20]$. When meadow clover and trifolium repens is included in the mixture in the quantity of 5 and $3 \mathrm{~kg} / \mathrm{ha}$ respectively - productivity of grasslands increases by $1.5-2$ times, which is equivalent to the introduction of $61-95 \mathrm{~kg} / \mathrm{ha}$ of mineral nitrogen on cereals $[8,16,20,22,30]$.

However, in modern meadow grasses growing it is impossible to completely abandon the application of nitrogen fertilizers, even on legumes, as a result, there will be a sharp decline in yield, and in a few years - the degeneration of grass. Experiments conducted by V.A. Tiuldiukov [19] showed that without the use of fertilizers the yield of grass was at the level of 1.7-2.4 t/ha of dry matter, at the average norms $\left(\mathrm{N}_{120}\right.$ and $\left.\mathrm{N}_{180}\right)-3.9-6.0$ t/ha.

Therefore, it is very important for obtaining high productivity of perennial grasses to ensure the correct selection of their species and fertilizer rates, taking into account the soil and climatic zones of cultivation.

Materials and methods. Experimental work was carried out during 2017-2020 at the Institute of Agriculture of the Carpathian Region of NAAS (Lishnia village, Drohobych district, Lviv region). The experiment was based on sod-podzolic surface-gleyed medium-acid loamy soils.

In early spring, the formed grass-stand was fertilized with nitrogen, phosphorus and potassium fertilizers in the form of ammonium nitrate, 
granular superphosphate and potassium salt. We used a complex of microelements in the chelated form of microfol combi for foliar feeding with grass.

Agricultural techniques in the experimental plots were generally accepted, except for the elements that were studied in the experiment. From perennial grasses were sown: perennial fenugreek - variety Drohobytskyi 16, timothy grass - Pidhirianka, meadow fescue - Liulinetska 3, meadow clover - Peredkarpatska 33 and bird's-foot trefoil - Aiaks.

The selection of grass mixtures and their ratios were determined in accordance with the recommendations for the area.

Harvest accounting was performed according to the method of the Institute of Feeds NAAS by the division-weight method. The content of absolutely dry matter was determined by drying plant samples in a thermostat at a temperature of $100-105{ }^{\circ} \mathrm{C}$ (DSTU ISO 6497:2005). Determination of species, botanical composition, yield structure and grass density was performed by sampling the green mass from the plots of each variant of $0.25 \mathrm{~m}^{2}$ from the first and third repetitions, which were divided into botanical-economic groups: cereals, legumes, grasses (DSTU 6017:2008). The total nutritional value of feed was calculated in feed units, based on data from their own chemical analyzes and taking into account the coefficients of their digestibility according to the A.P. Dmitrochenko (1972) method. Processing and generalization of research results was performed using the variance method of mathematical statistics (Dospekhov B.A., 1985) using Microsoft Excel software [2, 9].

Results and discussion. The dry matter yield of the mixtures varied depending on the level of fertilizer and the species composition of the grassstand. The collection of dry mass of sown grasses over the years of the study varied depending on the level of fertilizer in the range from 1.53 to $12.82 \mathrm{t} / \mathrm{ha}$, and on average over four years - from 2.15 to $9.08 \mathrm{t} / \mathrm{ha}$. This indicator was the lowest in areas fertilized only with phosphorus-potassium fertilizers at the rate of $\mathrm{P}_{60} \mathrm{~K}_{60}$. Additional application of $30 \mathrm{~kg}$ of nitrogen per 1 ha in the spring increased the dry matter harvest from 0.68 to 1.48 $\mathrm{t} / \mathrm{ha}$, depending on the variant of the grass mixture (Table 1).

Increasing the nitrogen dose to $60 \mathrm{~kg} / \mathrm{ha}$ in the variant with timothy meadow and meadow clover increased this figure to $8.56 \mathrm{t} / \mathrm{ha}$, or $1.79 \mathrm{t} / \mathrm{ha}$ compared to the control, which is $26.4 \%$. Further increase of the nitrogen dose to $90 \mathrm{~kg} / \mathrm{h}$ a reduced the dry matter collection to $7.58 \mathrm{t} / \mathrm{ha}$. This is due to a decrease in the share of meadow clover from $28.5 \%$ in areas fertilized with phosphorus-potassium fertilizers $\mathrm{P}_{60} \mathrm{~K}_{60}$, to $17.0 \%$ in areas fertilized with complete mineral fertilizers at the rate of $\mathrm{N}_{90} \mathrm{P}_{60} \mathrm{~K}_{60}$. 
Feeding the grass by applying over the vegetative mass of the drug microfol combi on the background of complete mineral fertilizers $\mathrm{N}_{30} \mathrm{P}_{60} \mathrm{~K}_{60}$ contributed to some increase in dry matter yield: $1.03-2.10 \mathrm{t} / \mathrm{ha}$ more compared to phosphorus-potassium fertilizer and $0.35-1.00 \mathrm{t} / \mathrm{ha}$ more in comparison with $\mathrm{N}_{30} \mathrm{P}_{60} \mathrm{~K}_{60}$ fertilizer.

Over the years of research, a significant difference in the yield of dry mass per area unit was observed. So, if in the first year of use of grass, from 1 hectare was collected depending on the level of fertilizer $2.49-12.82 \mathrm{t} / \mathrm{ha}$ of dry weight, on the second $-2.86-11.3 \mathrm{t} / \mathrm{ha}$, on the third and fourth accordingly only $1.73-6.88$ and $1.53-6.91 \mathrm{t} / \mathrm{ha}$.

\section{Dry mass yield of sown grassland depending on fertilizer and composition of grass mixtures, $\mathrm{t} / \mathrm{ha}$}

\begin{tabular}{|c|c|c|c|c|c|c|}
\hline $\begin{array}{c}\text { Grass mixtures } \\
\text { (types of grasses and } \\
\text { seeding rates) }\end{array}$ & Fertilizers & 2017 & 2018 & 2019 & 2020 & $\begin{array}{l}\text { Ave- } \\
\text { rage }\end{array}$ \\
\hline \multirow{5}{*}{$\begin{array}{l}\text { Timothy-grass } \\
\text { (6 kg/ha), meadow } \\
\text { clover }(16 \mathrm{~kg} / \mathrm{ha})\end{array}$} & $\begin{array}{l}\mathrm{P}_{60} \mathrm{~K}_{60}- \\
\text { background (B) }\end{array}$ & 11,93 & 8,15 & 4,42 & 2,58 & 6,77 \\
\hline & $\mathrm{B}+\mathrm{N}_{30}$ & 12,36 & 9,46 & 5,04 & 2,94 & 7,45 \\
\hline & $\begin{array}{l}\mathrm{B}+\mathrm{N}_{30}+ \\
\text { treatment } \mathrm{MK}^{*}\end{array}$ & 12,82 & 10,33 & 5,13 & 2,93 & 7,80 \\
\hline & $\mathrm{B}+\mathrm{N}_{60}$ & 11,45 & 10,62 & 6,63 & 5,54 & 8,56 \\
\hline & $\mathrm{B}+\mathrm{N}_{90}$ & 11,50 & 10,33 & 4,34 & 4,16 & 7,58 \\
\hline \multirow{5}{*}{$\begin{array}{l}\text { Timothy-grass } \\
(4 \mathrm{~kg} / \mathrm{ha}), \text { orchard } \\
\text { grass }(6 \mathrm{~kg} / \mathrm{ha}), \\
\text { perennial fenugreek } \\
(6 \mathrm{~kg} / \mathrm{ha}), \text { meadow } \\
\text { fescue }(6 \mathrm{~kg} / \mathrm{ha})\end{array}$} & $\begin{array}{l}\mathrm{P}_{60} \mathrm{~K}_{60}- \\
\text { backgrour }\end{array}$ & 2,49 & 2,86 & 1,73 & 1,53 & 2,15 \\
\hline & $\mathrm{B}+\mathrm{N}_{30}$ & 4,84 & 4,80 & 2,19 & 2,48 & 3,58 \\
\hline & $\begin{array}{l}\mathrm{B}+\mathrm{N}_{30}+ \\
\text { treatment } \mathrm{MK}^{*}\end{array}$ & 5,01 & 6,68 & 2,61 & 2,70 & 4,25 \\
\hline & $\mathrm{B}+\mathrm{N}_{60}$ & 5,08 & 5,87 & 3,45 & 4,54 & 4,73 \\
\hline & $\mathrm{B}+\mathrm{N}_{90}$ & 6,64 & 8,34 & 4,20 & 4,50 & 5,92 \\
\hline \multirow{5}{*}{$\begin{array}{l}\text { Timothy-grass } \\
\text { (4 kg/ha), orchard } \\
\text { grass }(6 \mathrm{~kg} / \mathrm{ha}), \\
\text { perennial fenugreek } \\
(6 \mathrm{~kg} / \mathrm{ha}), \text { meadow } \\
\text { clover }(3 \mathrm{~kg} / \mathrm{ha}), \\
\text { bird's-foot trefoil } \\
(3 \mathrm{~kg} / \mathrm{ha})\end{array}$} & $\begin{array}{l}\mathrm{P}_{60} \mathrm{~K}_{60}- \\
\text { background (1) }\end{array}$ & 9,58 & 7,62 & 5,25 & 3,74 & 6,55 \\
\hline & $\mathrm{B}+\mathrm{N}_{30}$ & 11,51 & 9,91 & 4,91 & 3,88 & 7,55 \\
\hline & $\begin{array}{l}\mathrm{B}+\mathrm{N}_{30}+ \\
\text { treatment } \mathrm{MK}^{*}\end{array}$ & 10,90 & 11,30 & 5,83 & 4,98 & 8,25 \\
\hline & $\mathrm{B}+\mathrm{N}_{60}$ & \begin{tabular}{|l|}
11,41 \\
\end{tabular} & 11,12 & 6,88 & 6,91 & 9,08 \\
\hline & $\mathrm{B}+\mathrm{N}_{90}$ & 10,38 & 7,77 & 5,87 & 4,27 & 7,07 \\
\hline \multicolumn{2}{|l|}{$\begin{array}{r}\mathrm{LSD}_{0,5}, \mathrm{t} / \mathrm{haFactor} \mathrm{A} \\
\text { Factor B }\end{array}$} & $\begin{array}{l}0,20 \\
0,25 \\
0,44\end{array}$ & $\begin{array}{l}0,27 \\
0,33 \\
0,57\end{array}$ & $\begin{array}{l}0,08 \\
0,11 \\
0,22\end{array}$ & $\begin{array}{l}0,09 \\
0,20 \\
0,25\end{array}$ & \\
\hline
\end{tabular}


And first of all it concerns sites fertilized only by phosphoruspotassium fertilizers. This is due to the loss of yielding grass-stands of legumes and cereals.

Thus, the highest yield of dry mass $(9.08 \mathrm{t} / \mathrm{ha})$ was provided by sowing of meadow clover, bird's-foot trefoil and a mixture of cereal grasses (timothy-grass, orchard grass, perennial fenugreek) when applying mineral fertilizers at a dose of $\mathrm{N}_{60} \mathrm{P}_{60} \mathrm{~K}_{60}$. When sowing timothy-grass with meadow clover on a similar agricultural background, the dry matter yield was $8.56 \mathrm{t} / \mathrm{ha}$.

According to the averaged data during 2017-2020, the quantity of meadow clover in the experiment was $17.0-28.6 \%$ and the quantity of bird's-foot trefoil was $11.3-22.8 \%$. The content of legumes in the variants with the introduction of starting doses of nitrogen $\left(\mathrm{N}_{30}\right)$ was $29.0-28.6 \%$, while in the background variant $-28.5-37.2 \%$ in the green mass. And further increase in doses of nitrogen fertilizers significantly reduced the amount of legumes in the grass. In the variant with sowing only cereal grasses, their content in the herbage was $72.7-86.0 \%$, self-seeding grasses $13.9-27.3 \%$ in the green mass (Table 2).

2. Botanical and economic composition of grass-stands depending on fertilizer and composition of grass mixtures, average for 2017-2020,\% of the total yield

\begin{tabular}{|c|c|c|c|c|c|}
\hline $\begin{array}{c}\text { Grass mixtures } \\
\text { (types of grasses and } \\
\text { seeding rates) } \\
\end{array}$ & Fertilizers & $\begin{array}{c}\text { Meadow } \\
\text { clover }\end{array}$ & $\begin{array}{l}\text { Bird's- } \\
\text { foot } \\
\text { trefoil }\end{array}$ & Cereals & $\begin{array}{c}\text { Different } \\
\text { herbs }\end{array}$ \\
\hline 1 & 2 & 3 & 4 & 5 & 6 \\
\hline \multirow{5}{*}{$\begin{array}{l}\text { Timothy-grass } \\
(6 \mathrm{~kg} / \mathrm{ha}), \\
\text { meadow clover } \\
(16 \mathrm{~kg} / \mathrm{ha})\end{array}$} & $\begin{array}{l}\mathrm{P}_{60} \mathrm{~K}_{60}- \\
\text { background (B) }\end{array}$ & 28,5 & - & 58,3 & 13,3 \\
\hline & $B+N_{30}$ & 28,6 & - & 57,4 & 14,0 \\
\hline & $\begin{array}{l}\mathrm{B}+\mathrm{N}_{30}+ \\
\text { treatment } \mathrm{MK} *\end{array}$ & 23,2 & - & 61,1 & 15,5 \\
\hline & $\mathrm{B}+\mathrm{N}_{60}$ & 22,7 & - & 65,1 & 12,2 \\
\hline & $\mathrm{B}+\mathrm{N}_{90}$ & 17,0 & - & 70,8 & 12,2 \\
\hline \multirow{5}{*}{$\begin{array}{l}\text { Timothy-grass } \\
(4 \mathrm{~kg} / \mathrm{ha}), \text { orchard } \\
\text { grass }(6 \mathrm{~kg} / \mathrm{ha}), \\
\text { perennial fenugreek } \\
(6 \mathrm{~kg} / \mathrm{ha}), \text { meadow } \\
\text { fescue }(6 \mathrm{~kg} / \mathrm{ha})\end{array}$} & $\begin{array}{l}\mathrm{P}_{60} \mathrm{~K}_{60}- \\
\text { background (B) }\end{array}$ & - & - & 72,7 & 27,3 \\
\hline & $\mathrm{B}+\mathrm{N}_{30}$ & - & - & 80,5 & 19,4 \\
\hline & $\begin{array}{l}\mathrm{B}+\mathrm{N}_{30}+ \\
\text { treatment } \mathrm{MK} *\end{array}$ & - & - & 76,0 & 23,8 \\
\hline & $B+N_{60}$ & - & - & 80,6 & 19,3 \\
\hline & $\mathrm{B}+\mathrm{N}_{90}$ & - & - & 86,0 & 13,9 \\
\hline
\end{tabular}




\begin{tabular}{|l|l|c|c|c|c|}
\hline \multicolumn{1}{|c|}{1} & \multicolumn{1}{|c|}{2} & 3 & 4 & 5 & 6 \\
\hline $\begin{array}{l}\text { Timothy-grass } \\
\text { (4 kg/ha), orchard } \\
\text { grass (6 kg/ha), } \\
\text { perennial fenugreek } \\
\text { (6 kg/ha), meadow }\end{array}$ & $\begin{array}{l}\mathrm{P}_{60} \mathrm{~K}_{60}- \\
\text { background (B) }\end{array}$ & 14,4 & 22,8 & 51,7 & 11,0 \\
\cline { 2 - 6 } $\begin{array}{l}\text { clover (3 kg/ha), } \\
\text { bird's-foot trefoil } \\
\text { (3 kg/ha) }\end{array}$ & $\begin{array}{l}\mathrm{B}+\mathrm{N}_{30}+ \\
\text { treatment MK* }\end{array}$ & 13,0 & 11,3 & 59,6 & 17,3 \\
\cline { 2 - 6 } & $\mathrm{B}+\mathrm{N}_{60}$ & 15,4 & 11,9 & 63,0 & 9,62 \\
\cline { 2 - 7 }$+\mathrm{N}_{90}$ & 13,8 & 13,3 & 62,3 & 10,6 \\
\hline
\end{tabular}

There is no clear dependence of the change in the content of the legume component in the green mass on the foliar feeding of grasses with the drug microfol combi.

Increasing the rate of application of nitrogen fertilizers in the experiment to $\mathrm{N}_{90}$ significantly reduced the percentage of sown legumes in the grass-stand and, as a consequence, led to a decrease in yield. Thus, if in the areas fertilized only with phosphorus-potassium fertilizers $\mathrm{P}_{60} \mathrm{~K}_{60}$, legumes in the grassland averaged $28.5-37.2 \%$ over the years of research, then in the areas fertilized with $\mathrm{N}_{30} \mathrm{P}_{60} \mathrm{~K}_{60}-21.0-29.0 \%$.

A further increase the nitrogen dose to $\mathrm{N}_{60}$ slightly reduced the content of the legume component in both grass mixtures: up to $22.7 \%$ on timothy-clover and in the mixture, which included meadow clover $(3 \mathrm{~kg} / \mathrm{ha})$ and bird's-foot trefoil (3 kg/ha), to $27.3 \%$. Application of $\mathrm{N}_{90}$ reduced the content of legumes in the grassland to $17.0 \%$ in the first and to $27.1 \%$ in the third grass mixture.

The purpose of growing legumes and cereals is to increase the production of digestible protein and fully provide with it a feed unit. In our case, $1 \mathrm{~kg}$ of dry mass of legume-cereal grass mixtures contains $0.60-0.92$ feed units, and digestible protein in the feed unit $-102-143 \mathrm{~g}$, which is fully consistent with the established zootechnical standards for feeding animals (Table 3).

Low saturation of the fodder unit with digestible protein was observed in the variants with sown cereal grasses - only 53.9-103 g. However, the feed of cereal grasses when applying nitrogen fertilizers was characterized by a sufficient content of feed units $-65-73 \mathrm{~g}$ in $1 \mathrm{~kg}$ of dry weight. As the nitrogen dose increased from 30 to $60 \mathrm{~kg} / \mathrm{ha}$, the yield of feed units increased. 
ISSN 0130-8521. Передгірне та гірське землеробство і тваринництво. 2021. Вип. 70 (2)

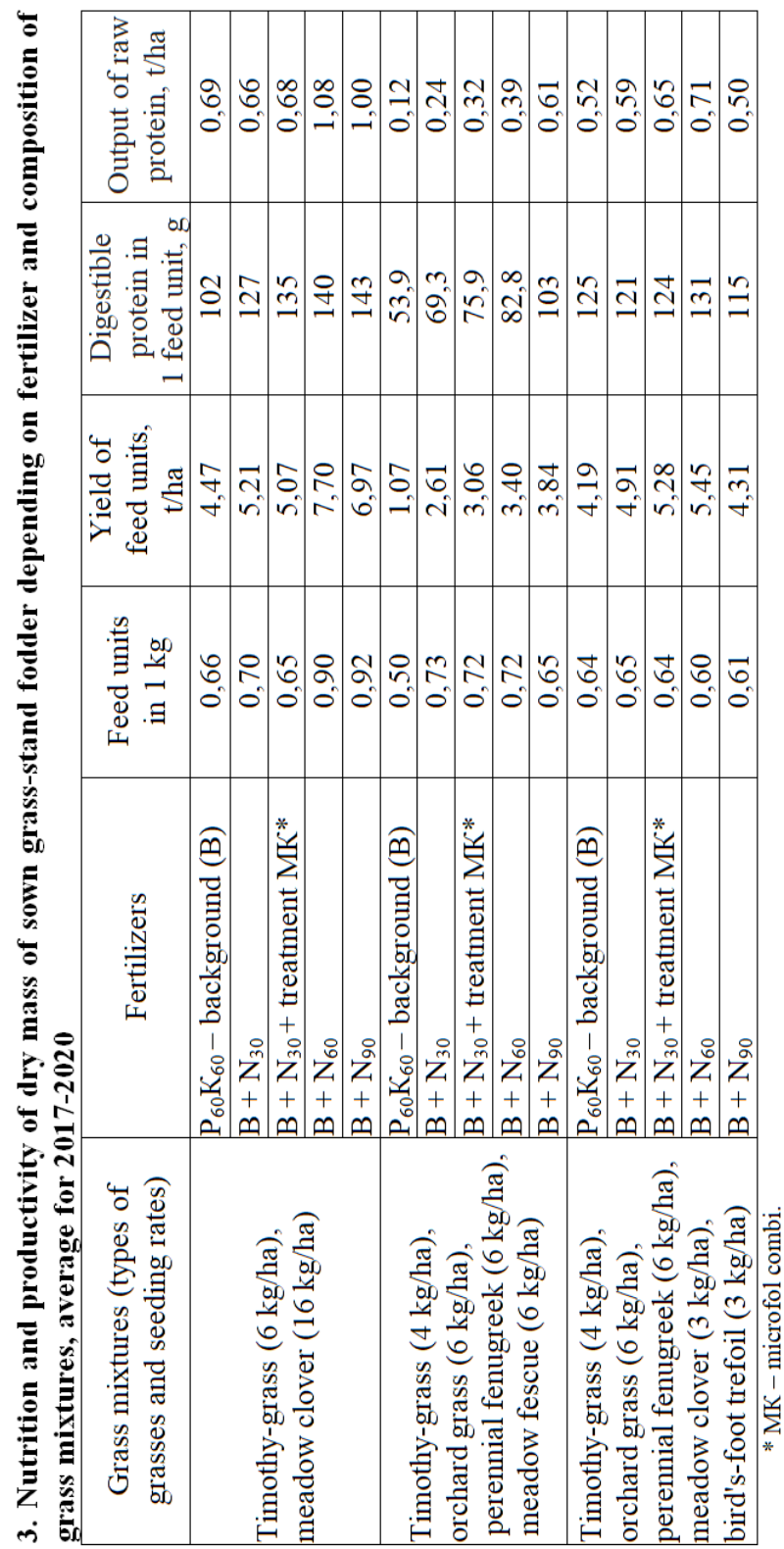


Conclusions. The highest yield with a dry matter of $9.08 \mathrm{t} / \mathrm{ha}$ is formed by sowing meadow clover, bird's-foot trefoil and a mixture of cereal grasses (timothy-grass, orchard grass, perennial fenugreek) when applying mineral fertilizers at a dose of $\mathrm{N}_{60} \mathrm{P}_{60} \mathrm{~K}_{60}$. During the sowing of timothygrass with meadow clover on a similar agricultural background, the dry matter yield was $8.56 \mathrm{t} / \mathrm{ha}$.

The use of microelements in the form of the drug microfol combi contributed to some increase in yield indicators, namely: on the grass mixture of timothy-grass $(6 \mathrm{~kg} / \mathrm{ha})$ and hybrid clover $(16 \mathrm{~kg} / \mathrm{ha})$ by 0.35 $\mathrm{t} / \mathrm{ha}$; cereal grassland $-0.67 \mathrm{t} / \mathrm{ha}$; on grassland of timothy-grass $(4 \mathrm{~kg} / \mathrm{ha})$, perennial fenugreek $(6 \mathrm{~kg} / \mathrm{ha})$, perennial fenugreek $(6 \mathrm{~kg} / \mathrm{ha})$, meadow clover ( $3 \mathrm{~kg} / \mathrm{ha})$ and bird's-foot trefoil ( $3 \mathrm{~kg} / \mathrm{ha})-0.70 \mathrm{t} / \mathrm{ha}$ of dry mass.

Increasing the rate of application of nitrogen fertilizers in the experiment to $\mathrm{N}_{90}$ significantly reduced the percentage of sown legumes in the grass and, as a consequence, led to a decrease in yield.

It was found that the mixture of timothy-grass with meadow clover provides the highest yield of feed units $(7.07 \mathrm{t} / \mathrm{ha}$ ) and digestible protein $(1.08 \mathrm{t} / \mathrm{ha})$ with the use of complete mineral fertilizer. The supply of one feed unit with digestible protein reaches $140 \mathrm{~g}$.

\section{Список використаної літератури}

1. Агроекобіологічні основи створення та використання лучних фітоценозів / М. Т. Ярмолюк та ін. Львів, $2013.304 \mathrm{c}$.

2. Бабич А.О. Методика проведення дослідів з кормовиробництва та годівлі тварин. Київ, 1994. 80 с.

3. Багаторічні бобово-злакові травосуміші в інтенсивному кормовиробництві / Л. М. Єрмакова та ін. Вісник аграрної науки. 1999. № 6. С. $36-37$.

4. Байер Я., Петр И., Черны В. Формирование урожая основных сельскохозяйственных культур / пер. с чеш. 3. К. Благовещенской. Москва : Колос, 1984. 367 c.

5. Боговін А. В., Пташнік М. М., Дудник С. В. Відновлення продуктивних, екологічно стійких трав'янистих біогеоценозів антропотрансформованих едафотопах. Київ, 2017. 356 с.

\section{References}

1. Agroecobiological bases of creation and use of meadow phytocenoses / M. T. Yarmoliuk et al. Lviv, 2013. 304 p.

2. Babych A. O. Methods of conducting experiment on forage production and animal feeding. Kyiv, 1994. $80 \mathrm{p}$.

3. Perennial legume-cereal mixtures in intensive fodder production / L. M. Yermakova et al. Visnyk ahrarnoi nauky. 1999. No 6. P. 36-37.

4. Baier Ja., Petr I., Cherny V. Formation of the harvest of the main agricultural crops / per. s chesh. Z. K. Blagoveshhenskoj. Moscow : Kolos, 1984. 367 p.

5. Bohovin A. V., Ptashnik M. M., Dudnyk S. V. Restoration of productive, ecologically sustainable herbaceous biogeocenosices on anthropotransformed edaphotopes. Kyiv, 2017. 356 p.

6. Vlokh V. H., Kyrychenko N. 
6. Влох В. Г., Кириченко Н. Я., Когут П. М. Луківництво. Київ : Урожай, 2003. $118 \mathrm{c}$.

7. Давидюк М. Ф., Белаш В. А., Кочик Г. М. Створення високопродуктивних сінокосів за ресурсоощадливою технологією. Корми $i$ кормовиробниитво. 2001. Вип. 47. С. 207-210.

8. Давидюк О. М. Вплив травосумішок на продуктивність пасовищ та якість кормів. Вісник аграрної науки. 2001. № 7. С. 71.

9. Доспехов Б. А. Методика полевого опыта (с основами статистической обработки результатов исследований). Изд. 5-е, доп. и перераб. Москва, 1985. $351 \mathrm{c.}$

10. Лазарев Н. Н., Благовещенский К. А. Многолетние травы в интенсивном молочном скотоводстве Западной Европы. Известия ТСХА. 2015. Вып. 6. С. 101-107.

11. Макаренко П. С. Влияние режимов использования и норм азотных удобрений на продуктивность бобовозлакового травостоя и качество корма. Корма и кормопроизводство. 1989. Вып. 28. С. 42-47.

12. Марцінко Т. І. Вплив удобрення на продуктивність та ботанікогосподарський склад сіяних лучних агроценозів. Передгірне та гірське землеробство $i$ тваринництво. 2020. Вип. 68 (1). С. 135-145.

13. Марцінко Т. І., Дзюбайло А. Г., Карасевич Н. В. Продуктивність бобовозлакового травостою залежно від удобрення в умовах Передкарпаття. Передгірне та гірське землеробство $i$ тваринництво. 2019. Вип. 66. С. 145155.

14. Особливості формування різновікових лучних травостоїв залежно від поверхневого поліпшення / У. О. Котяш та ін. Передгірне та гірське землеробство $i$ тваринництво. 2019. Вип. 66. С. 117-129.
15. Сайко
B.
Ф. Проблема

Ya., Kohut P. M. Meadow cultivation. Kyiv : Urozhai, 2003. 118 p.

7. Davydiuk M. F., Belash V. A., Kochyk H. M. Creation of highly productive hayfields on resource-saving technology. Kormy i kormovyrobnytstvo. 2001. Issue 47. P. 207-210.

8. Davydiuk O. M. Influence of grass mixtures on pasture productivity and fodder quality. Visnyk ahrarnoi nauky. 2001. No 7. P. 71.

9. Dospehov B. A. Methodology of field experiment (with basics of statistical processing of rescarch results). 5th ed. Moscow, 1985. $351 \mathrm{p}$.

10. Lazarev N. N., Blagoveshhenskij K. A. Perennial grasses in intensive dairy farming in Western Europe. Izvestija TSKhA. 2015. Issue 6. P. 101-107.

11. Makarenko P. S. Influence of the modes of use and norms of nitrogen fertilizers on the productivity of leguminous-cereal herbage and the quality of forage. Korma $i$ kormoproizvodstvo. 1989. Issue 28. P. 42-47.

12. Martsinko T. I. Influence of fertilizer on productivity and botanical and economic composition of sown meadow agrocenoses. Peredhirne ta hirske zemlerobstvo i tvarynnytstvo. 2020. Issue 68 (1). P. 135-145.

13. Martsinko T. I., Dziubailo A. H., Karasevych N. V. Productivity of leguminous and cereal grasses depending on fertilizer in the conditions of Precarpathians. Peredhirne ta hirske zemlerobstvo i tvarynnytstvo. 2019. Issue 66. P. 145-155.

14. Features of formation of different age meadow grasses depending on surface improvement / U. O. Kotyash et al. Peredhirne ta hirske zemlerobstvo $i$ tvarynnytstvo. 2019. Issue 66. P. 117-129.

15. Saiko V. F. The problem of providing soils with organic matter. Visnyk ahrarnoi nauky. 2003. No 5. P. 5-9.

16. Satsyk V. O. Productivity of legumes and legume-cereal mixtures 
забезпечення грунтів органічною речовиною. Вісник аграрної науки. 2003. № 5. C. 5-9.

16. Сацик В. О. Продуктивність бобових трав та бобово-злакових травосумішок при укісному використанні. Вісник аграрної науки. 2000. № 5. С. 67-68.

17. Тебердиев Д. М., Родионова А. В. Эфективность удобрений на долголетнем сенокосе. Кормопроизводство. 2015. № 10. С. 3-7.

18. Тоомре Р. И. Долголетние культурные пастбища. Москва : Колос, 1996. $399 \mathrm{c}$.

19. Тюльдюков В. А., Прудников А. Д., Самойлова Л. Г. Формирование многолетних агрофитоценозов на мелиорированных землях при различных способах их использования и уровнях минерального питания. Известия ТСХА. 1995. Вып. 4. С. 14-36.

20. Яценко М., Приступа В. Конюшина - перспективна культура. Тваринництво України. 2000. № 3/4. С. 29.

21. A plant-functional-type approach tailored for stakeholders involved in field studies to predict forage services and plant biodiversity provided by grasslands / $\mathrm{M}$. Duru et al. Grass and Forage Science. 2014. Vol. 70. P. 2-18.

22. Benjamin F. Tracy. Conditions that favor clover establishment in permanent grass swards Grassland Science. 2014. Vol. 61. P. $34-40$.

23. Dry-matter yield of Lotus varieties in white clover grass mixtures in a lowfertility soil / A. H. Marshall et al. Grass and Forage Science. 2014. Vol. 69, Issue 2. P. 294-302.

24. Fychan R., Sanderson R., Marley C. L. Effects of harvesting red clover/ryegrass at different stage of maturity on forage yield and quality. Grassland Science in Europe. 2016. Vol. 21 : The multiple roles of grassland in the European bioeconomy. P. 323-325.

25. Huyghe C., De Vliegher A., when used indirectly. Visnyk ahrarnoi nauky. 2000. No 5. P. 67-68.

17. Teberdiiev D. M., Rodionova A. V. Fertilizer efficiency in long-term haymaking. Kormoproizvodstvo. 2015. No 10. P. 3-7.

18. Toomre R. I. Long-term cultivated pastures. Moscow : Kolos, 1996. 399 p.

19. Tiul'diukov V. A., Prudnikov A. D., Samojlova L. G. Formation of perennial agrophytocenoses on reclaimed lands with different methods of their use and levels of mineral nutrition. Izvestija TSKhA. 1995. Issue 4. P. 14-36.

20. Yatsenko M., Prystupa V. Clover is a promising crop. Tvarynnytstvo Ukrainy. 2000. No 3/4. P. 29.

21. A plant-functional-type approach tailored for stakeholders involved in field studies to predict forage services and plant biodiversity provided by grasslands / M. Duru et al. Grass and Forage Science. 2014. Vol. 70. P. 2-18.

22. Benjamin F. Tracy. Conditions that favor clover establishment in permanent grass swards. Grassland Science. 2014. Vol. 61. P. 34-40.

23. Dry-matter yield of Lotus varieties in white clover grass mixtures in a low-fertility soil / A. H. Marshall et al. Grass and Forage Science. 2014. Vol. 69, Issue 2. P. 294-302.

24. Fychan R., Sanderson R., Marley C. L. Effects of harvesting red clover/ryegrass at different stage of maturity on forage yield and quality. Grassland Science in Europe. 2016. Vol. 21 : The multiple roles of grassland in the European bioeconomy. P. 323-325.

25. Huyghe C., De Vliegher A., Golinkski P. European grasslands overview: Temperate region. Grassland Science in Europe. 2014. Vol. 19. P. 29-40.

26. Isselstein J., Kayser M. Functions of grasslands and their potential in delivering ecosystem services. Grassland Science in Europe. 2014. Vol. 
Golinkski P. European grasslands overview: Temperate region. Grassland Science in Europe. 2014. V. 19. P. 29-40.

26. Isselstein J., Kayser M. Functions of grasslands and their potential in delivering ecosystem services. Grassland Science in Europe. 2014. Vol. 19. P. 199-214.

27. Long-term time series of legume cycles in a semi-natural montane grassland: evidence for nitrogen-driven grass dynamics? / T. Herben et al. Functional Ecology. 2017. Vol. 31. P. 1430-1440.

28. Potential of legume-based grassland-livestock systems in Europe / Luscher A. et al. Grass and Forage Science. 2014. Vol. 69. P. 206-228.

29. Relationships between botanical composition, yield and forage quality of permanent grasslands over the first growth cycle / D. Andueza et al. Grass and Forage Science. 2015. Vol. 71. P. 366-378.

30. Weggler K., Thumm U., Elsaesser M. Development of Legumes After Reseeding in Permanent Grassland, as Affected by Nitrogen Fertilizer Applications. Agriculture. 2019. Vol. 9, Issue $\quad 10.207 . \quad$ URL: https://www.mdpi.com/2077-0472/9/10/207 (last accessed: 20.09.2021).
19. P. 199-214.

27. Long-term time series of legume cycles in a semi-natural montane grassland: evidence for nitrogen-driven grass dynamics? / T. Herben et al. Functional Ecology. 2017. Vol. 31. P. 1430-1440.

28. Potential of legume-based grassland-livestock systems in Europe / Luscher A. et al. Grass and Forage Science. 2014. Vol. 69. P. 206-228.

29. Relationships between botanical composition, yield and forage quality of permanent grasslands over the first growth cycle / D. Andueza et al. Grass and Forage Science. 2015. Vol. 71. P. 366-378.

30. Weggler K., Thumm U., Elsaesser M. Development of Legumes After Reseeding in Permanent Grassland, as Affected by Nitrogen Fertilizer Applications. Agriculture. 2019. Vol. 9, Issue $\quad 10.207 . \quad$ URL: https://www.mdpi.com/20770472/9/10/207 (last accessed: 20.09.2021). 